\title{
THE DOMINATION OF PATRIARCHISM IN INHERITANCE CUSTOMARY SYSTEMS
}

\author{
I Kadek Adhi Dwipayana and Nyoman Astawan \\ Indonesian and Regional Language Education Study Program, PGRI Mahadewa University of Indonesia \\ Seroja Street, North Denpasar, Indonesia \\ Corresponding Author: adhidwipa88@gmail.com
}

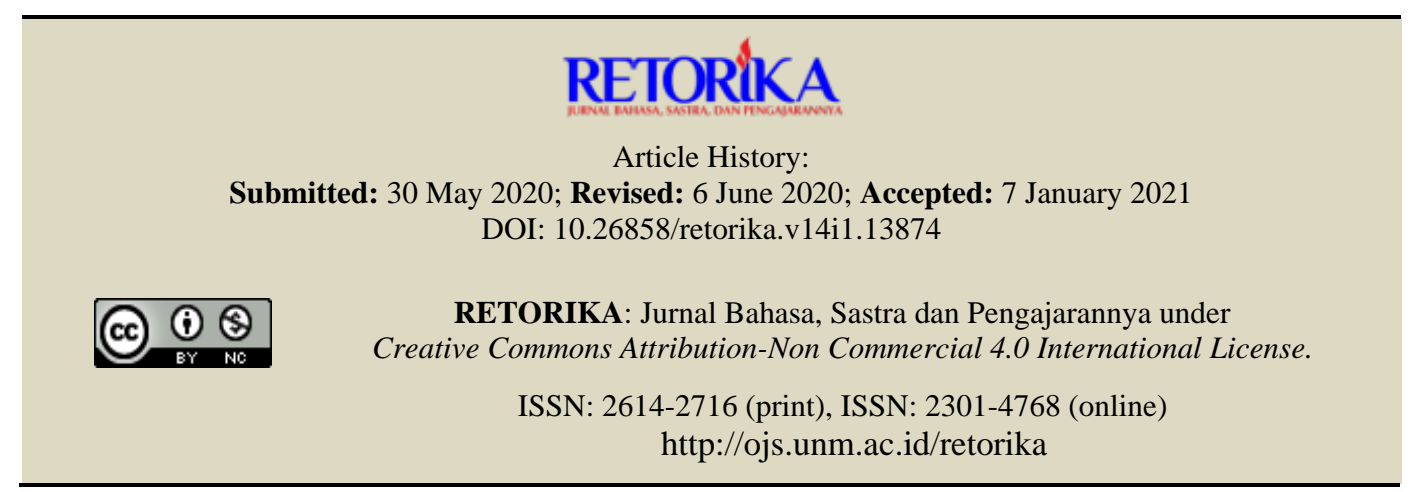

\begin{abstract}
There are two objectives to be achieved by this study, first revealing the dominance of patriarchism in systems of inheritance. Secondly, revealing efforts to represent resistance to the customary systems of inheritance in literary works of Balinese cultural background. Theoretically, this research has an urgency for the development of literary discourse, while practically giving an understanding to the public about the attitude of inheritance issues in Bali. Theories of literary sociology and feminism are used as a basic foundation for analyzing the problems offered in this study. The main data sources of the research are two novels by Oka Rusmini, namely Tarian Bumi and Kenanga and two short stories by Putu Fajar Arcana, namely Sulasih and Wardani Marriage. After the data has been collected using the literature study method, then it is analyzed based on a descriptive qualitative method. The results show that the dominance of patriarchism in the adat system of inheritance has created social inequality. The customary inheritance system rules in literary works (Tarian Bumi, Kenanga, Sulasih, and Pernikahan Wardani) are monolithic, showing no partiality towards girls. Daughters who have "ninggal kedaton" (married) do not get a family "gunakaya" inheritance (gono gini). Efforts to resist patriarchal domination as represented in various literary works, starting with the character Luh Sadri, took repressive actions to sue for the distribution of inheritance, deceit, and be tough.
\end{abstract}

Keywords: Domination of Patriarchism, Inheritance System, Literary Works Balinese Cultur

Literary work as a cultural product is born through the sensitivity of the author which is then interpreted into artistic narrative patterns. The problems presented in literary works are a form of processing the realities of the author's life as part of a cultural society (Ratna, 2005). Literary works always contain elements of a certain ideology, literature is never constructed through a void (Swingewood, 1972). Through literary work, the author tries to voice the world view of a social group, trans-individual subject with all its problematic complexities (Goldman in Yasa, 2014). 
The ideology that Balinese writers often discuss and criticize in their literary works is patriarchism. Patriarchism is a belief in a monolithic social system of kinship which is dominated and controlled by men. Patriarchal understanding is rooted in a dual dichotomic tradition of thought, such as dark/ light, day/ night, good/ bad, black/ white, male/ female, and others (Arivia, 2003: 163). Patriarchism in social life has grown and developed into two forms, namely personal and institutional (Dwipayana and Artajaya, 2018). Personal patriarchism is reflected in one's excessive fanaticism in viewing men as subjects or centers of social control. Meanwhile, institutionalized patriarchism is reflected in the customary system or traditions that favor men.

The issue of the hegemony of patriarchal ideology in Balinese life has always been an interesting topic, until now it has not been thoroughly discussed in literary works. Patriarchism has consciously animated the lives of people who have given birth to social inequality, including in Bali. The practice of patriarchism in the customary and traditional systems in Bali places women in a subordinate position, while men play the role of aggressor. Fakih (1996) states that men are the benchmark and standard for defining the role of women, not women are measured based on their qualities. Patriarchism gave birth to policy mechanisms that function to control women's rights and mobility as well as men's access to the maximum benefits of pragmatism. One of the social inequalities due to patriarchism in Bali is the inheritance customary system.

Patriarchism in the context of the inheritance customary law system in Bali is evident in the rules which state that boys as heirs have the right to inheritance from the family, including the use of wealth (gono-gini wealth), while girls do not get the title of heir. The term management (male) is the main reference in the distribution of family / ancestral inheritance rights. The purusa (son) is said to have a bigger duty to continue the family's swadarma (obligations) so that the swa-dikara (right) to get a family inheritance is also greater. Meanwhile, girls are said to have fewer rights to family inheritance, moreover, girls who have passed away (left home due to marriage) are not entitled to the family inheritance. In fact, inheritance in the concept and view of the Balinese Hindu tradition is not only related to economic wealth, but also about matters of a religious nature (yadnya ceremony, sanggah/ merajan). Before the issuance of the Decree of Pasamuhan Agung III, 2010 regarding the renewal of inheritance rights, Balinese women were always in a subordinate position and tended to experience discriminatory actions in the distribution of inheritance rights. However, in the contemporary context based on the decision of Pesamuhan Agung III MUDP Bali Number 01/KEP/PSM3/MDP Bali/X/2010, girls who died in a limited state (married) have received a cultural defense entitled to one-third of the wealth (gono-gini) family, while women who die full time (change religion) have no right at all to inheritance from the family but they can still be given a soul fund (provision).

The polemic about the imbalance of the inheritance customary system and other sociocultural problems has always been an iconic topic for local Balinese authors. Darma (2008) states that the phenomenon of locality regarding customs and the impact of tourism has always been the main theme in every literary work raised by Balinese authors. Through the media of literary works they try to address and dissect the problems of Balinese locality with their perspective and critical thinking and try to voice the struggles of social groups. Panji Tisna is known as an author of the Balai Pustaka era who has popularized themes that breathe locality into modern Indonesian literary works, such as the cultural struggle of Balinese women against the shackles of tradition contained in the novel Sukreni Gadis Bali (1936). Likewise, there were other Balinese writers who critically reviewed Balinese sociocultural problems, starting from Nyoman Rasta Sindhu in the short story When Kentongan was Beaten in Bale Banjar (1963), Putu Wijaya in the novel Bila Malam Bertambah Malam (1971), Gde Aryantha Soethama in a collection of short stories. Mandi Api (2006), I Wayan Artika in the novel Incest (2008), I Made Adnyana Ole in a collection of short stories, Gadis Suci Painting Sacred Signs in a Sacred Place (2018), Cok Sawitri in Sutasoma (2009), Sonia Piscayanti in a collection of short stories for Women Tanpa Nama (2015), and many other young Balinese authors. 
Apart from the authors mentioned above, Oka Rusmini through her work entitled Tarian Bumi (2000), and Putu Fajar Arcana through her two short stories entitled Sulasih (2001) and Marriage Wardani (2003) with visionary have given new colors to literary themes raised the issue of Balinese customary law. The two novels by Oka Rusmini and the two short stories by Putu Fajar Arcana have used as research subjects with a realistic consideration that these works represent the sociocultural problems experienced by most people in Bali, especially those related to the dominance of patriarchism in the inheritance customary system. The polemic which is triggered by inheritance inequality until now has never subsided in the social dynamics in Bali. This is understandable because Bali is currently in a transition period so that the contestation between traditional and modern ideologies cannot be avoided. The contestation between traditional and modern ideologies can be understood as a form of confusion among Balinese people in determining their firm attitude, turning away, or sticking to tradition (Dwipayana and Adnyana, 2019). Based on the logical view above, the researcher is interested in conducting research on the Domination of Patriarchism in the Inheritance Customary System: Socio-Femenism Studies in Balinese Local Color Literature. There are two main objectives that become the urgency of this research, namely to determine the forms of patriarchal domination of the inheritance customary system in literary works and to describe the resistance efforts of characters in literary works to the dominance of patriarchy as a form of representation of the author's.

\section{METHOD}

There are two main objectives of this research, first to describe the representation of the dominance of patriarchal ideology in cultural literature. Second, explaining the resistance efforts represented by the author in cultural literature. Referring to the main objective above, this research design uses a qualitative descriptive method that describes data based on cultural symptoms in literary works with the sociological theory of literature and feminism as the basis for analysis. This research has the following characteristics: (1) contextual, (2) collaborative, (3) interpretative, (4) interactive, and (5) the researcher as a human instrument/ key instrument. The research data comes from the novel by Oka Rusmini, namely Tarian Bumi, two short stories by Putu Fajar Arcana entitled Sulasih and Marriage Wardani. Data on the representation of patriarchal hegemony and authors' resistance efforts in literature were collected using the literature study method with reading and notetaking techniques. The procedural steps for the reading and note technique are (1) carrying out a comprehensive reading of literary works (Tarian Bumi, Wardani, and Sulasih's short stories) to identify and interpret problems regarding forms of the arrogance of patriarchal ideology and efforts of author resistance in literary works. (2) recording data on cultural issues regarding patriarchal arrogance in the Balinese traditional inheritance system. This data collection procedure follows the principles of cultural studies which are interpreted in literary works. The data that has been collected through literature study using reading and note-taking techniques are analyzed and interpreted using a qualitative descriptive method which has several operational steps, namely data reduction, data presentation, and drawing conclusions. Simultaneous data reduction was carried out through the identification and coding process. This is then followed by classification and interpretation using sociological theories of literature and feminism. After the data has passed the reduction, the problems studied in the study are presented in a descriptive qualitative manner. The reduction result data is presented using narrative descriptions or descriptions using words. It should be emphasized that the data presented using the narrative description is the result of identification and classification carried out at the reduction stage. The final step in data analysis is drawing conclusions from the findings in the data presentation process. Conclusions are drawn after the data obtained is presented using a narrative description. Analysis and interpretation of data are based on sociological theory of the theory of traditional law of inheritance and feminist theory to see the extent to which women in literary works are subordinated to the hegemony of patriarchal ideology in the traditional system of inheritance of Balinese society. The three stages interact with each other and have a connection, starting with data collection and ending with drawing conclusions. 
RETORIKA: Jurnal Bahasa, Sastra, dan Pengajarannya, Vol. 14, No. 1, February 2021, pp. 1-13

\section{FINDINGS AND DISCUSSION}

\section{Findings}

The novel Tarian Bumi and Kenanga by Oka Rusmini tells about the complex problems of customs and traditions in Bali. This novel not only discusses the rigid system of social stratification and the authoritative system of intercaste marriage but also about the imbalance of the inheritance customary system in Balinese life caused by the dominance of patriarchism. The short story of Sulasih and Wardani's Marriage by Putu Fajar Arcana has an almost similar theme, namely about the polemic of inheritance customary law that does not side with women. If in Wardani's short story Marriage, the main character has to do an arranged marriage on the grounds of getting sentana/ male descendants as the successor of family responsibilities. Meanwhile, Sulasih's short story describes the sacrifice of a Balinese woman who gets psychological pressure to be able to give birth to male offspring as the successor to the royal family of the puri.

\section{The Domination of Patriarchism in the Costumary System of Inheritance in Balinese Cultural Literature}

Men with the term purusa in the context of the inheritance customary system get more privileges in matters of inheritance rights than girls. Girls who have died or left the family home due to marriage have lower family inheritance rights (property), even in practice sometimes girls do not get any rights. The patriarchal system in Balinese society provides a small enough space for women who die from the palace to get a share of the family inheritance. Luh Sadri has to accept such facts with relief as a woman who grows up and lives in a traditional environment. The submission of Balinese women to a patriarchal ideology is very visible in the rules for the distribution of inheritance rights that do not favor Luh Sadri as a daughter. Even though Luh Sadri has worked hard and carried out her obligations as a daughter to help sustain the family's economy, in the eyes of tradition Luh Sadri has weak power over family inheritance because most of these rights fall in the hands of her brother, I Wayan Sasmitha. The psychological closeness between Luh Gumbreg and Luh Sadri (between mother and child) has no power whatsoever to change the reality that Luh Sadri still does not have the right to inheritance (property) in the family. Girls seem not to get cultural defense from their mothers in the midst of the dominance of the patriarchal system. Oka Rusmini, through the Earth Dance, presented that tradition really cannot be compromised and through her hegemony has castrated Luh Sadri's feminine rights in the context of Balinese customary inheritance.

"Menurut Adat Bali, perempuan memang
tidak memiliki hak waris. Kalau Sadri tidak
kawin, dia memang punya hak lebih tinggi
dari Telaga, iparnya. Tetapi sekarang Sadri
sudah kawin. Otomatis hak itu menjadi
miliki Telaga" (Tarian Bumi, 158-160).

Translation:

"According to Balinese custom, women do not have inheritance rights. If Sadri is not married, he does have higher rights than Telaga, his brother-in-law. But now Sadri is married. Automatically the right belongs to Telaga "(Tarian Bumi, 158-160).

The issue of inheritance rights also happened to Ida Ayu Telaga when she chose to marry Wayan Sasmitha, someone who was not from the Brahmin or aristocratic circles. Almost similar to Luh Sadri, Telaga is also said to have passed away from the palace, but even more, extreme, Telaga turun wangsa, because married with a male who from jaba wangsa so that the Griya family sanctioned by removing Telaga from soroh (clan) of the Brahmana wangsa through the Pattiwangi ritual (ritual reduction of nationality). The family of the griya tries to maintain the purity of the traditions passed on by their ancestors so that the rejection of Telaga marriage is considered as justification even though it sacrifices the rights of Telaga. The influence of the castration traditional system on Balinese society, causes the aristocracy to seek to preserve the purity of their blood or descendants, so that marriage on an equal basis/ pepadan is the most ideal choice (Gunada in Sadnyini, 2016: 123). Telaga did not get a penny on the family inheritance, Telaga was also not given a jiwa dana (provision of wealth in the form of property) when married to Wayan Sasmitha. Telaga has conducted a ngerorod marriage (kawin lari), this marriage is carried out secretly because it does 
not get the approval of the Griya family. Wignjosoebroto (2002) states that traditions in Bali are guarded by authoritative traditions, even if their legality is strengthened by family ethics. Violation of family ethics can have fatal consequences, namely that the perpetrator is subject to sanctions based on a family agreement, either in the form of ritual performance or being expelled from the dynasty or clan. Violation of family ethics is referred to as tulah (disrespect) or durwaka (disobedience) to ancestors so that it must be subject to sanctions, both social and psychological.

\begin{abstract}
"Telaga tahu, dua orang perempuan dalam rumah ini tidak mengharapkan kehadirannya. Mereka percaya kedatangan telaga ke rumah mereka hanya membawa runtutan kesialan saja. Apalagi Telaga benar-benar tidak membawa satu butir berlian pun. Semua perhiasannya dia tinggalkan di Griya. Telaga juga tidak membawa pakaiannya, karena beranggapan sial jadinya bila semua barangnya dibawa. Barang-barang itu miliki Nenek, milih Ibu. Kalau Telaga menikah dengan laki-laki Brahmana, keluarga besar akan membekali kepergiannya dengan barang-barang itu. Karena telah menikah dengan Wayan, tidak ada keluarga griya yang datang membawa perangkat pakaian dan perhiasan untuk Telaga. Apalagi dia kawin tanpa pamit" (Tarian Bumi, 148).
\end{abstract}

Translation:

Telaga knows, the two women in this house didn't expect her to be there. They believe the arrival of Telaga to their house only brings a series of bad luck. Moreover, Telaga doesn't carry a single diamond. All the jewelry he left in the Griya. Telaga also did not bring its clothes, because it thought it would be bad luck if all its belongings were brought. Grandma's belongings, choose Mother. If Telaga marries a Brahmin man, his extended family will equip him with these things. Because he was married to Wayan, none of the family of the house came to bring clothes and jewelry for Telaga. Moreover, he married without saying goodbye" (Tarian Bumi, 148).

The position of Balinese women who are subordinated in the context of inheritance as in the case experienced by Telaga actually contradicts the teachings of Hinduism. In the
Manawa Dharmasastra book, it is written that "But to sisters, brothers will give some parts of their portion, each a quarter of its share; those who refuse to give it will be excluded." This implies that in fact in the teachings of Hinduism, women still get part of the inheritance rights or soul funds (provision of wealth) from the family to live household life.

Oka Rusmini represents Luh Gumbreg as a traditional woman who obeys and is consistent with traditional orders even though the patriarchal traditional system hurts her female conscience. Luh Gumbreg did not budge when Luh Sadri demanded some of the inheritance rights of the gunakaya (gono-gini wealth) that Gumbreg collected when he was married. Luh Gumbreg did not fully side with Luh Sadri as his only daughter, instead, he showed a stiff, conservative attitude, and objected when Luh Sadri demanded a portion of the inheritance rights to the 20-acre gunakaya land (gono-gini wealth). However, there is something interesting about the character of Luh Gumbreg, he was constructed by Oka Rusmini to have a dualistic nature regarding the inheritance rights system for his children, especially Luh Sadri. On the one hand, Luh Gumbreg shows the principle of siding with patriarchal hegemony which prioritizes sons to family inheritance (rights), but on the other hand Luh Gumbreg softens and tries to make peace with the situation.

The patriarchal tradition does give Balinese men swadikara (rights) a bigger inheritance than women because the swadarma (obligations) that they have to bear are also very large. Balinese men have responsibilities, such as carrying out their obligations as traditional citizens, maintaining the continuity of the sanggah/merajan (a place of family worship), the obligation to carry out the yadnya ceremony (a ceremony that is sincere to ancestors, humans, and gods), continuing the Purusa line others (Windia, 2015). The notion of inheritance in the Balinese traditional concept is not only about material assets, nonmaterial (heirlooms, sanggah/ merajan) are also included in it. That concept is what Luh Gumbreg adheres to as a traditional woman. That is the reason Wayan Sasmitha always gets primary treatment. Wayan Sasmitha is a purusa who continues the family lineage and frees Luh Gumbreg from bad karma when he dies according to the teachings of Balinese Hinduism. His belief is rooted in the beliefs of the Balinese people that are inherited genealogically and born 
RETORIKA: Jurnal Bahasa, Sastra, dan Pengajarannya,

Vol. 14, No. 1, February 2021, pp. 1-13

from a consensus that is very difficult to break because of the belief in magical religious values (Artadi in Sadnyini, 2014: 186). As a woman, Luh Sadri will ninggal kedaton (out of the house due to marriage) so that she will leave her swadarma (obligation) in her origin house, then Luh Sadri will exercise her rights and responsibilities as a wife in the husband's family house. Luh Gumbreg ignored the slightest bit of Luh Sadri's complaint even though he was accused of not being able to behave fairly to his children. Luh Gumbreg remains in the position of carrying out the best possible traditions that have been passed down genealogically by his ancestors.

\section{"Kau dan wayan milikku yang terpenting. Aku mencintai kalian." \\ "Waktu aku kecil, Meme biasa memberikan
bagian lebih banyak untuk Bli
dibandingkan aku." \\ "Wayan laki-laki. Porsi tanggung jawabnya lebih besar. Bukankah rumah ini dia yang merawat? Memberi kita makan, dan dia juga jungkir balik bekerja agar kita tetap hidup" (Tarian Bumi, 159).}

Translation:

"You and wayan are the most important. I love you all."

"When I was a kid, mother used to give more wealth for Bli than me."

"Wayan is a boy. The portion of the responsibility is bigger. Isn't this the house he takes care of? Feeds us, and he also works somersaults to keep us alive". (Tarian Bumi, 159).

Luh Sadri's character is represented as a woman who tries to break tradition. Luh Sadri is the representation of most Balinese women who experience the fate of being marginalized in the context of inheritance. Through her courage to demand rights, Luh Sadri was able to present a polemic of distributing inheritance rights for girls, which in reality is still a serious debate. The patrilineal system or kepurusaan system (male) in Balinese society does give birth to different treatment between boys and girls. The system is still believed and considered logical because men have a heavier obligation to continue the family tradition, while girls will leave their origin home to become someone else's wife so that their rights and obligations are considered to be broken.
Through the character Luh Sadri, Oka Rusmini was able to present different thoughts on the debate on swadikara (rights) and swadarma (obligations) like girls. A thought emerged and developed that the swaradma (obligation) of girls does not always break up even though they have ninggal kedaton (married). The responsibilities and obligations of girls who ninggal kedaton (married) continue, they can still pay attention, provide for, and care for their parents when they are sick (Sudantra, 2011).

\begin{abstract}
"Aku juga bekerja. Pagi-pagi sudah bangun, memotong jaje uli. Agak siang aku ke pasar. Sore harinya aku bawa jaje uli pada para pemesan. Aku menjungjungnya dengan besek besar. Aku juga bekerja keras" (Tarian Bumi, 159).
\end{abstract}

Translation:

I work too. In the morning I wake up, cut the jaje uli. Later that afternoon I went to the traditional market. In the afternoon I brought jaje uli to the customers. I lifted it with a large basket. I also worked hard (Tarian Bumi, 159).

Luh Sadri's tough stance regarding the distribution of inheritance rights was not in vain. Luh Sadri was able to convince Luh Gumbreg that he deserves a part of the inheritance of the gunakaya (gono-gini wealth) that Gumbreg collected when he was a family. Luh Gumbreg's maternal instincts were knocked out by trying to be less rigid and more compromising on her daughter's situation. Luh Gumbreg wants to end the inheritance-sharing polemic that involves him and his daughter. Luh Gumbreg is heartened to give Luh Sadri jiwa dana (wealth provision) in the form of a piece of land as long as Luh Sadri wants to invite her husband to beg in front of Luh Gumbreg.

“Dengar! Aku akan memberimu tanah 5 are kalau kau datang bersama laki-laki yang kau kawini itu. Jangan pernah berharap aku akan memberi satu genggam tanahku untukmu kalau bukan laki-laki itu yang bicara padaku. Aku ingin lihat, laki-laki atau perempuankah dia! Tanah ini miliku. Aku yang membuatnya ada. Di tanah ini seluruh keringatku tertanam. Kau pulang sekarang. Aku capek!” (Tarian Bumi, 163).

Translation: 
"Listen to me! I will give you 5 acres of land if you come with the man you married. Don't ever expect me to give a handful of my land to you unless that guy talks to me. I want to see, boy or girl! This land is mine. I made it there. On this ground all my sweat was planted. You go home now. I am tired!" (Tarian Bumi, 163).

As has been said before, the customs of the people in Bali adhere to a patrilineal system that recognizes the terms purusa and pradana. Purusa has the duties and responsibilities to carry out the obligations inherited from the ancestors, starting from carrying out the responsibilities of indigenous people, carrying out the yadnya ceremony, maintaining sanggah/ merajan (a place of family worship), and so on. In the management system, boys have a position as sentana from the Purusa lineage. Sentana according to Korn (1932: 29) comes from the word "santana" which means offspring. In the context of Balinese custom, the word sentana is pinned to boys who then carry on their rights and obligations as well as family descent. Different conditions will be found if a family only has one daughter. The family concerned will raise Sentana Rajeg to carry on family responsibilities. Sentana rajeg is a term for girls whose position is enhanced as sentana children who are then considered equal to men (Windia, 2015). In the novel Tarian Bumi, the female character who plays the position of sentana rajeg is Ida Ayu Sagra Pidada.

\begin{abstract}
"Nenek seorang perempuan yang luar biasa keras. Dia adalah seorang putri bangsawan kaya. Sejak kecil nenek selalu bahagia. Apa pun yang dimintanya selalu terpenuhi. Ayah nenek seorang pendeta yang memiliki banyak sisia, orang-orang setia dan hormat pada griya. Otomatis sejak mudanya nenek punya kedudukan yang lebih tinggi dan terhormat dibandingkan perempuan-perempuan lain di griya"
\end{abstract}

"Konon, nenek sangat kaya dan cantik. Karena tidak memiliki anak laki-laki, orang tua nenek menjodohkannya dengan lakilaki miskin” (Tarian Bumi, 14).

Translation:

"Grandma is an extremely tough woman. She is a daughter of a rich noble. Since childhood, my grandmother was always happy. Whatever he asked for was always fulfilled. Grandmother's father was a pastor who had many sisia, people loyal and respectful to the house. Automatically since she was young, grandmother had a higher and more respectable position than other women in the house. "

"That said, grandma was very rich and beautiful. Because they do not have a son, their grandmother's parents arranged marriage to a poor man" (Tarian Bumi, 14).

Sentana rajeg is an alternative that is possible if a family only gives birth to girls. In addition, the appointment of sentana rajeg is generally carried out when girls are having a wedding ceremony. This shows that the issue of inheritance will affect the choice of type of marriage by Balinese people, as Ida Ayu Sagra Pidada did by choosing the type of marriage nyentanain/ nyeburin. In the context of nyentana marriage, the male party is married to the woman. Women act as purusa (men) and men have the status of pradana (women). This marriage case is usually carried out by families who do not have a sentana or male lineage as heirs or administrators of the female family's swadarma (obligations). In the novel Tarian Bumi, the case of nyentanain marriage was carried out by the character Ida Ayu Sagra Pidada and Ida Bagus Tugur. Ida Bagus Tugur can be seen as giving up his rights and obligations in the original community as a male Purusa to enter the women's community and become pradana (women). Ida Bagus Tugur holds the predicate of dualistic masculinity and femininity towards this nyentana marriage system. As a man who is sedentary, on the one hand, Ida Bagus Tugur must carry out his duties as a successor to the family responsibilities of the woman or act as a purusa (male) but on the other hand, he also takes over the role of pradana (woman) and must submit against his wife's decision.

"Terwujudnya impian itu telah membuat Ida Bagus Tugur merasa baru memiliki kekuasaan yang sesungguhnya. Laki-laki itu lupa, dia punya seorang anak laki-laki. Dia juga lupa telah beristri. Dia lupa bahwa pernah nyentanain" (Tarian Bumi: 15).

Translation:

"The realization of that dream has made Ida Bagus Tugur feel that he has just had real power. The man forgot, he has a son. He also forgot to have a wife. He forgot that he had ever nyentanain". (Tarian Bumi: 15). 
The dualistic predicate of Ida Bagus Tugur in the Nyentana marriage system means that his freedom as a man is regulated by the traditions of the female side. Every decision that is taken must get the consent of the woman so that she feels that she is being restrained both socially and culturally. In Bali, nyentana actors get a negative and inferior label, which is known as paid bangkung. Etymologically, the term paid bangkung means "drawn by a female pig." The negative term paid bangkung is a form of ridicule and harassment made by Balinese themselves for Balinese men who are under women's control.

The inheritance system which is patrilineal in nature gave rise to the idea of a matchmaking for Ida Ayu Sagra Pidada with the premise of getting sentana which will continue the swadarma (obligation) of the woman's family. This marriage was initially accepted with legawa, but later it caused psychological problems for Ida Ayu Sagra Pidada because she didn't get Ida Bagus Tugur's love. Ida Ayu Sagra Pidada represents Balinese women who suffer from an arranged marriage with the argument of getting sentana to carry on family obligations. Ida Ayu Sagra Pidada is under the control and shadow of the patriarchy in matters of inheritance, so she must be willing to accept the fact of marrying a man who doesn't like her. Ida Ayu Sagra Pidada's unhappiness during her life with her husband Ida Bagus Tugur can be seen clearly from her conversation with her grandson Ida Ayu Telaga about the sacredness of marriage. The biggest regret of Ida Ayu Telaga Pidada is not having the opportunity to get to know her husband well before having a sacred marriage. This made her resent the system and tradition that must force her to marry a man who doesn't love her.

\footnotetext{
"Kelak, kalau kau jatuh cinta pada seorang laki-laki, kau harus mengumpulkan berates-ratus pertanyaan yang harus kau simpan. Jangan pernah ada orang yang tahu bahwa kau sedang menguji dirimu apakah kau memiliki cinta yang sesungguhnya atau sebaliknya. Bila kau bisa menjawab beratus-ratus pertanyaan itu, kau mulai memasuki tahap berikutnya. Apa untungnya laki-laki itu untukmu? Kau harus berani menjawabnya. Kau harus yakin dengan kesimpulan-kesimpulan yang kau munculkan sendiri. Setelah itu, endapkan! Biarkanlah jawaban-jawaban dari ratusan pertanyaanmu itu menguasai
}

otakmu. Jangan pernah menikah hanya karena kebutuhan atau dipaksa oleh sistem. Menikahlah dengan laki-laki yang mampu memberimu ketenangan, cinta, dan kasih. Yakinkan dirimu bahwa kau memang memerlukan laki-laki itu dalam hidupmu. Kalau kau tak yakin, jangan mencoba mengambil risiko (Tarian Bumi, 17-18).

Translation:

"Later, when you fall in love with a boy, you have to collect a hundred questions that you must save. Never have anyone know that you are testing yourself whether you have true love or vice versa. If you can answer those hundreds of questions, you begin to enter the next stage. What's in it for the man in you? You must dare to answer it. You must be sure of the conclusions you come up with yourself. After that, settle! Let the answers to your hundreds of questions dominate your brain. Never marry out of necessity or compelled by the system. Marry a man who can give you peace, love, and compassion. Convince yourself that you need that man in your life. If you're not sure, don't try to take chance (Tarian Bumi, 17-18).

The marriage type 'Nyentana' was also carried out by Wardani in a short story entitled "Wardani's Marriage" by Putu Fajar Arcana. Wardani received pressure from his parents to marry a man named Ketut Berartha by entering into a the marriage type nyentana. Almost similar to the novel Tarian Bumi, the argument that made Wardani's parents forcing him to marry Berartha was to get sentana (heir) who could later carry on the family's customary swadharma (obligations). In this marriage case, Wardani became the purusa (male) party and carried out the marriage process to Ketut Berartha, who played the role of the pradana (female) party. As a woman, Wardani is said to have no power against her father's will to seek sentana, even though with the consequence of giving up her love affair with a man named Kurnia. The patriarchal system has made Wardani's life full of problems that cut into her female mind.

\footnotetext{
"Padahal sesungguhnya mereka tidak rela kalau seluruh warisan jatuh ke tangan orang lain. Aku dikawinkan dengan istilah nyentana, Kur. Itu artinya, lelaki yang dilamar oleh perempuan. Cara ini pengecualian dari tata cara patrilineal yang
} 
dianut adat di Bali. Keluargaku mendatangkan sentana. Hanya sewaktu dilakukan upacara aku diberikan predikat sebagai purusa, itu lelaki dalam artian spiritual, dan Beratha berbalik menjadi prdana, menjadi perempuan meski secara fisik ia lelaki" (Pernikahan Wardani, 147).

Translation:

"In fact, they are not willing if the entire inheritance falls into the hands of other people. I was married to the term nyentana, Kur. That means men who are proposed by women. This method is an exception to the patrilineal customs adhered to in Balinese customs. My family brought Sentana. Only when the ceremony was performed was I given the title of purusa, that was male in a spiritual sense, and Beratha turned into pradana, became a woman even though he was physically a man "(Wardani Marriage, 147).

A somewhat different perspective can be captured in Oka Rusmini's novel Tarian Bumi and Fajar Arcana's short story Marriage Wardani. According to Oka Rusmini, Nyentana marriage has shackled the power of Ida Bagus Tugur because he traditionally plays a dualistic swadarma (responsibility) in the pradana's house. However, according to Putu Fajar Arcana, the most disadvantaged party in the nyentana marriage system is the woman herself. Wardani is said to be in a subordinate position in the patrilineal system which provides opportunities for men to act as aggressors so that many benefit Ketut Beratha, including spending the ancestral heritage belonging to the Wardani family. In this condition as a woman, Wardani is helpless and resigned to accept the nature that has been outlined by tradition.

"Coba, kamu bayangkan Kur, Kurnia, bagaimana aku bisa menikah dengan lakilaki semacam ini. Aku sudah tahu bahwa aku seperti sapi yang digiring menuju ruang penjagalan. Tapi apalah dayaku sebagai perempuan Bali yang senantiasa harus menurut kehendak orang tua. Apalagi aku anak tunggal dan perempuan, orang tuaku selalu turut campur pada kehidupanku. Mereka selalu beralasan, demi kebahagiaan masa depanku. Demi kelangsungan keluarga" (Pernikahan Wardani, 147).

Translation:

\begin{abstract}
"Try, you imagine Kur, Kurnia, how can I marry a man like this. I already know that I am like a cow being led into the slaughterhouse. But what about my power as a Balinese woman who always has to be according to the wishes of my parents. Moreover, I am an only child and a girl, my parents always interfere in my life. They always excuse, for the sake of my future happiness. For the sake of family continuity" (Marriage Wardani, 147).
\end{abstract}

Wardani is portrayed as a weak figure against patriarchal hegemony in the context of inheritance so that he has to sacrifice himself into the pit of suffering married to Ketut Berartha to get the sentana of the family's wishes. After marrying Ketut Berartha, most of Wardani's life suffered until the legacy of the Wardani family was used for fun by Ketut Berartha.

A form of patriarchal arrogance is also found in a short story entitled "Sulastri" by Putu Fajar Arcana. The character Gung Aji shows his hegemony by practicing polygamy many times in the hope of getting a son as the heir who will continue the lineage of the puri family. Polygamy was carried out by Gung Aji without the consent of his wives as a form of hegemony as a penglisir puri (elders/leaders). Puri in a socio-historical perspective in community life in Bali is a symbol of hegemony with egocentric and authoritative provisions both among the puri family itself and the community. In the internal kinship of the castle, there is a tradition that must be continued and carried out by boys. The birth of a boy is expected to maintain the purity of the royal dignity of the puri family so that it remains firm in the eyes of the indigenous community.

"Sejak melahirkan Gek Bulan tahun 1967 silam, Gung Biang, sudah mengkhawatirkan kelanjutan perkawinannya dengan Gung Aji. Sebagai perempuan di lingkungan puri, ia paham suaminya pasti menginginkan keturunan laki-laki. Kekhawatiran itu akhirnya menjadi kenyataan ketika dua tahun kemudian Gung Biang kembali melahirkan anak perempuan, Gek Bintang. Hanya tida hari setelah melahirkan, Gung Aji memutuskan untuk mengawini sepupunnya sendiri, Biang Sruni. Sayangnya perkawinan itu tak berumur panjang karena Biang Sruni meninggal dalam sebauh kecelakaan pesawat di rawa-rawa dekat Bandara Ngurah Rai." 
Namun, duka Gung Aji hanya bertahan sekitar sebulan setelah jenazah Biang Sruni dikremasi. Ia segera menyunting Biang Rai, saudara jauh dari Puri Klungkung" (Sulasih, 13).

Translation:

"Since giving birth to Gek Bulan in 1967, Gung Biang has been worried about the continuation of his marriage to Gung Aji. As a woman in the puri environment, she understood that her husband would want male offspring. That worry finally came true when two years later Gung Biang gave birth to another daughter, Gek Bintang. Only three days after giving birth, Gung Aji decided to marry his cousin, Biang Sruni. Unfortunately, the marriage did not last long because Biang Sruni died in a plane crash in a swamp near Ngurah Rai Airport.

"However, Gung Aji's grief only lasted about a month after Biang Sruni's body was cremated. He immediately edited Biang Rai, a distant relative of Puri Klungkung" (Sulasih, 13).

The authoritative puri tradition has suppressed the courage of Gung Aji's wives to refuse. The figure of Gung Aji is said to have not received massive resistance from his wives and relatives in his efforts to carry out polygamy to realize the hope of having a son who will protect the honor of the puri family. The strong desire of the Gung Aji figure to have a son as the heir represents Gung Aji's conservative attitude in maintaining the status quo as a penglingsir puri. The figure of Gung Aji feels comfortable as penglingsir (leader) of the castle so that his position as the status quo will be more secure if he has a son to succeed the throne of the castle. The idea of an heir and the throne had blinded Gung Aji's conscience, thus committing tyrannical acts by polygamy repeatedly and rejecting the birth of his daughters.

"Kamu Cuma bisa beri saya anak perempuan. Kelanjutan dan kehormatan puri hanya bisa ditegakkan dari keturunan laki-laki, ujar Gung Aji suatu malam. Biang Rai paham. Ia tak menjawab. Tangannya tetap secara cekatan mejejaitan karena besk purname. Di sebelahnya Gung Biang juga acuh tak acuh. Ia pura-pura tak begitu memperhatikan ucapan Gung AJi. Ujung- ujungnya sudah bisa ditebak, Gung Aji pasti akan kawin lagi" (Sulasih, 13).

Translation:

"You can only give me a daughter. Continuity and honor of the castle can only be enforced from male descendants, said Gung Aji one night. Biang Rai understood. He didn't answer. His hands are still deftly aligned because of the full game. Next to him, Gung Biang was also indifferent. He pretended not to pay much attention to Gung AJi's words. In the end, Gung Aji will marry again" (Sulasih, 13).

Gung Aji was in a state of mental turmoil when Biang Rai gave birth to a daughter just like his first wife. The birth of a real child was not expected by an ambitious aristocratic man like the character Gung Aji. As a noble, Gung Aji feels ashamed of having a daughter and has not been able to continue the male tradition in the puri family community. Gung Aji's fanaticism towards the tradition in the puri is non-negotiable. There is no longer any dialogical space to simply compromise for his wives, the birth of a son is an absolute necessity. This attitude of Gung Aji can be captured as a form of arrogance and arrogance of the Puri nobility. This attitude of Gung Aji also represents in general Balinese men who carry out psychological oppression against Balinese women on the pretext of wanting sons to inherit the family.

"Biang Rai, sejak semula saya menikahimu karena Gung Biang tidak memenuhi permintaan Ajung, untuk mendapatkan laki-laki di puri ini. Ajung malu sebagai pewaris puri yang dihormati, tidak bisa meneruskan tradisi laki-laki di sini. Ternyata kamu juga hanya memberi saya anak perempuan, ' kata Gung Aji. Gung Aji tetap bicara dari atas kursi. Kakinya disilangkan. Sementara dua istrinya menggelar tikar di lantai sambil tetap mejejaitan" (Sulasih, 13).

Translation:

"Biang Rai, from the beginning I married you because Gung Biang did not fulfill Ajung's request, to find a man in this puri. Ajung is embarrassed as a respected heir to the puri, unable to continue the male tradition here. It turned out that you also only gave me daughters,"said Gung Aji. Gung Aji continued to speak from the top of the chair. Her legs are crossed. Meanwhile, 
his two wives spread out the mats on the floor while still holding them together" (Sulasih, 13).

Jro Sulasih, the third wife of Gung Aji, also got pressure to get male offspring. As a woman wangsa jaba who entered the puri community, Sulasih felt very heavy psychological pressure to give birth to a son. The psychological pressure made Sulasih fearful if he gave birth to a daughter and was left out of the puri family. This fear arises because Sulasih is not willing to lose the luxury and honor of being a noble wife. Sulasih tried to fight back against the situation by lying to Gung Aji that she had given birth to a son. Sulasih has exchanged his baby girl for a baby boy belonging to a family from Java. This action was carried out by Sulasih as a form of despair towards the situation and psychological pressure that blocked her ability to think logically.

"Karena terus memberontak, satpam dan
polisi memutuskan membawa Jro Sulasih ke
ruangan direktur rumah sakit di lantai dua.
Ditemani seorang perawat, direktur tampak
sudah menunggu. Ketika Jro Sulasih
masuk, perawat itu mengatakan kepada
direktur bahwa bayi laki-laki dalam
gendongan Jro Sulasih bukan bayinya
sendiri. Bayi itu milik sebuah keluarga dari
Jawa yang kebetulan lahir pada hari yang
sama" (Sulasih, 21).

Translation:

"Because they continued to rebel, the security guard and the police decided to take Jro Sulasih to the hospital director's room on the second floor. Accompanied by a nurse, the director seemed to be waiting. When Jro Sulasih entered, the nurse told the director that the baby boy in Jro Sulasih's arms was not the baby herself. The baby belonged to a family from Java who happened to be born on the same day" (Sulasih, 21).

Putu Fajar Arcana made an anticlimax conflict resolution in this Sulasih story. The plot of Sulasih's short story is very interesting and cannot be predicted beforehand, which ends with the theft of a baby boy from Sulasih's character. Putu Fajar Arcana seems to give a message that Balinese women have a very fragile side when they are subjected to massive pressure to give birth to sons as family heirs so that it can cause psychological shocks for women such as the figure Sulasih. In Sulasih's story, it can also be seen that in fact the birth of a child is completely the will of the Almighty which cannot be set by humans, not even a nobleman like the character Gung Aji.

\section{DISCUSSION}

The novel Tarian Bumi and Kenanga by Oka Rusmini, and the short story Marriage Wardani and Sulasih by Putu Fajar Arcana represent that patriarchism is very dominant in Balinese life, especially in the context of the inheritance customary system. The dominance of patriarchism has flourished and gave birth to inequality in social mobility and prolonged conflict in Bali. This domination certainly causes women to not get social protection from the customary system so that women are in a subordinate and marginalized position. Politically, the Balinese inheritance customary system can be seen as an attempt by men to strengthen patriarchic domination so that the role of women in the private and public spheres tends to be eliminated. Balinese female figures in literary works, such as Luh Sadri, Telaga, Ida Ayu Sagra Pidada, Wardani, and Sulasih are represented as victims of patriarchal hegemony which resulted in them being left out in the distribution of family inheritance. The female characters in these literary works are a general description of Balinese women who experience discrediting actions from the ideology of patriarchy.

The customary system of inheritance rights in Bali has determined that a girl's swadikara (rights) is lower than that of a boy. Women are forced to yield to tradition. The powerlessness of Balinese women towards tradition in the context of the inheritance system was experienced by Telaga figures, Luh Sadri, Ida Ayu Sagra Wardani, and Sulasih. The helplessness of Balinese female characters in the novel Tarian Bumi by Oka Rusmini and two short stories entitled Marriage Wardani and Sulasih by Putu Fajar Arcana can be interpreted as the author's self-criticism and resistance to patriarchism that is too dominating and overreaching in sociocultural life in Bali. Oka Rusmini and Fajar Arcana through their literary works try to describe a reality that women's rights in the distribution of inheritance rights are neglected by traditions that favor men. Narrative, this description of social 
reality should not only be interpreted as a form of women's defeat against tradition, instead, it is the substance of the representation of the gender struggle spirit of Oka Rusmini and Putu Fajar Arcana. The author wants to attract the sympathy of the reading community with the depiction of discrimination against Balinese women so that there are a reinterpretation and redefinition of the rigid traditional system in the inheritance customary system.

The figures of Balinese women in literary works are not only told of resigning to traditional destiny but carrying out the mission of fighting against patriarchism. The character of Luh Sadri is one of the real depictions of Oka Rusmini's struggle against the unfair distribution of inheritance rights for Balinese women. Luh Sadri reactionary demands that his mother be fair in distributing the family's gunakaya (gono-gini) inheritance. In fact, Luh Sadri did not hesitate to ask for part of Luh Gumbreg's wealth in the form of a 20-acre plot of land with logical and rational arguments. Luh Sadri can be interpreted as an antithetical depiction of the stereotype of Balinese women who are submissive and submissive when it comes to the problem of family gunakaya (gono-gini) inheritance. Balinese women generally prefer silence and are intuitive, but the character Luh Sadri makes a significant difference from frontal and reactionary demands for family inheritance rights. Even though Luh Sadri has reasons and a pragmatic mission, Luh Sadri's resistance to his mother by demanding inheritance rights has led to a new thought that even though Balinese women ninggal kedaton (leaving the house due to marriage) a girl's swadarma (obligation) to the family never ends. Luh Sadri's attitude in a narrative construction can be captured as an attempt by Oka Rusmini to break the negative stigma predicated on Balinese women as weak creatures. The depiction of the consistency of the character Luh Sadri can also be captured as Oka Rusmini's attempt to undermine the hegemony of authoritative patriarchism.

Ida Ayu Sagra Pidada and Wardani figures showed different reactions from Luh Sadri, they were not repressive and tended to accept the fate of tradition. Ida Ayu Sagra and Wardani characters are told as only children who did not refuse when they were arranged. Ida Ayu Sagra Pidada and Wardani were forced to practice the sentana type of marriage. A marriage that is based on political interests to get an heir as a continuation of the family tradition. The attitude of these two figures can be captured as an indirect effort to struggle by Oka Rusmini and Fajar Arcana or a struggle through silent means. Through the suffering of the figures Ida Ayu Sagra Pidada and Wardani, the author wants to attract the empathy of the reader by exposing a factual picture that nyentana marriage can actually cause complex internal conflicts. In addition, through these two female figures, patriarchism can be understood as a paradox for upholding social justice and the values of human freedom in determining a life partner.

The figure of Sulasih in the short story Sulasih by Putu Fajar Arcana responds to the hegemony of patriarchism in a reactionary manner and even takes extreme manipulative actions as a form of accumulated frustration over his psychological pressure from the figure of Gung Aji (a puri elder) to be able to give birth to a son. The birth of a boy is traditionally a dream and priority for most family couples in Bali, especially among aristocrats. In general, an assumption arises in Balinese society that a family is incomplete if it does not have sons. In the patrilineal tradition, boys are given a special position, even when their birth already has the title of heir and guardian of family honor. This traditional doctrine creates negative stereotypes for the existence of girls in the family and tradition. Gender equality is the material substance of the struggle that Putu Fajar Arcana has made through the representation of the Sulasih figure. A Fajar Arcana through Sulasih wants to provide an understanding of the ideal tradition that does not discriminate against Balinese women in community life. The position between men and women has the same degree, both socially and religiously. In the context of Hinduism, women are very honored, the concept of Tri Sakti places women (Dewi Saraswati, Dewi Sri, and Dewi Uma) as the main power of Tri Murti (Brahma, Wisnu, and Shiva).

\section{CONCLUSION}

The patriarchal system of Balinese society provides a small enough space for women who ninggal kedaton (married) to obtain a share of the family inheritance. Luh Sadri, as a woman who grew up and lived in a traditional environment, 
had to submit to a patriarchal ideology. Luh Sadri's character is represented as a woman who tries to break tradition. Luh Sadri can present a dilemma for Luh Gumbreg's character. Luh Sadri's tough stance regarding the distribution of inheritance rights was not in vain. Luh Sadri was able to convince Luh Gumbreg that he deserves a part of the inheritance of the gunakaya (gono-gini wealth) that Gumbreg collected when he was a family. The inheritance patrilineal system gave rise to the idea of matchmaking for Ida Ayu Sagra Pidada with the premise of getting sentana which will continue the swadarma (obligation) of the woman's family. Sentana rajeg is an alternative that is possible if a family only gives birth to girls. The arrogance of patriarchal form is represented by the figure of Gung Aji by repeatedly practicing polygamy in the hope of getting a son as the heir who will continue the lineage of the puri family.

\section{REFERENCES}

Adnyana Ole, M. (2018). Gadis Suci Melukis Tanda Suci di Tempat Suci. Singaraja: Mahima.

Arcana, P. F. (2003). Bunga Jepun. Jakarta: Kompas.

Arivia, G. (2006). Feminisme: Sebuah Kata Hati. Jakarta: Penerbit Buku Kompas.

Artika, I W. (2008). Incest. Yogyakarta: Penerbit Pinus.

Damono, S. Dj. (1984). Sosiologi Sastra Sebuah Pengantar Ringkas. Jakarta: Pusat Pembinaan dan Pengembangan Bahasa Departemen Pendidikan dan Kebudayaan.

Dwipayana, I. K. A. (2018). Potret Tirani dalam Praktik Sosiokultural di Bali dalam Cerpen Ketika Kentongan Dipukul di Bale Banjar Karya Nyoman Rasta Sindhu. Widyadari: Jurnal Pendidikan, 19 (2) 1-11.

Dwipayana, I. K. A. dan Gde S. A. (2018). Hegemoni Hukum Adat Bali dalam Karya Sastra Berlatar Sosiokultural Bali. Jurnal Kajian Bali, 08 (2) 85-105.

Dwipayana, I. K. A. dan I. B. Bawa Adnyana. (2019). Legitimasi Hukum Adat Bali dalam Karya Sastra Kultural. Retorika: Jurnal Pendidikan Bahasa, Sastra, dan Pengajarannya, 12 (2): 208-222.

Fakih, M. (1996). Analisis Gender dan Transformasi Sosial. Yogyakarta: Pustaka Pelajar.

Piscayanti, K. S. (2015). Perempuan Tanpa Nama. Singaraja: Mahima.

Putra, I N. D. (2008). Bali dalam Kuasa Politik. Denpasar: Arti Foundation.
Gung Aji's fanaticism towards the traditions in the puri is irreversible, the birth of a son is an absolute necessity. Sulasih feels very heavy psychological pressure to give birth to a boy. Sulasih is worried about losing the luxury and honor of being a noble wife when giving birth to a daughter.

\section{ACKNOWLEDGEMENT}

Thank you to all those who have supported the realization of this research. Especially to members of researchers who have provided educational conceptual contributions so that they can perfect this research for the better. Hopefully, the research results can be useful for academics and the development of compliance with literary discourse.

Ratna, N. K. (2005). Sastra dan Culture Studies: Representasi Fiksi dan Fakta. Yogyakarta: Pustaka Pelajar.

Rusmini, O. (2000). Tarian Bumi. Jakarta: Gramedia Pustaka Utama.

Rusmini, O. (2003). Kenanga. Jakarta: Grasindo

Sadnyini, I. A. (2016). Sanksi Perkawinan Terlarang di Bali Dulu dan Kini. Denpasar: Udayana University Press.

Sawitri, C. (2009). Sutasoma. Jakarta: Kaki Langit Kencana.

Shindu, N. R. (1969). Ketika Kentongan Dipukul di Bale Banjar. Horison, 1 (4): 27-29.

Soethama, G. A. (2006). Mandi Api. Jakarta: Kompas.

Swingewood, A. dan Diana L. (1972). The Sociology of Literature. London: Paladin.

Trisna, A. A. P. (1953). Sukreni Gadis Bali. Jakarta: Balai Pustaka.

Wellek, R. \& Austin W. (1977). Theory of Literature. Terjemahan Melani Budianta. 2014. Teori Kesusastraan. Jakarta: Pustaka Utama

Wijaya, P. (1971). Bila Malam Bertambah Malam. Jakarta: Pustaka Jaya.

Windia, W. (2015). Hukum Adat Bali: Aneka Kasus dan Penyelesaiannya. Gianyar: Dinas Kabupaten Gianyar bekerjasama dengan Udayana University Press, "Bali Shanti" Pusat Pelayanan dan Budaya Bali, dan Puslit Hukum Adat.

Yasa, I. N. (2012). Teori Sastra dan Penerapannya. Bandung: Karya Putra Darwati 